\title{
Water supply systems security: novel technologies for the online monitoring of unforeseeable events
}

\author{
A. G. Capodaglio \& A. Callegari \\ Department of Civil Engineering and Architecture, \\ University of Pavia, Italy
}

\begin{abstract}
Nowadays, the demand for more efficient and comprehensive online water monitoring technologies is spurred by more stringent regulatory constraints placed on water companies to provide high quality drinking water, increasing water resources scarcity, forcing water suppliers in many areas of the planet to rely on marginal water bodies, and the threat of hostile actions by political extremists and terrorists groups, that may willingly and deliberately cause contamination of an otherwise safe supply. Traditionally, quality parameters associated with drinking water provision were monitored using routine grab samples followed by laboratory analysis. This approach only allowed the capture small data sets, mostly unrepresentative of the true variance at the source, and allowed potentially important events to occur undetected. This paper examines state-of-the-art technologies for the online monitoring of water quality in supply water systems. Keywords: online monitoring, drinking water, system security, water quality, inorganic pollutants, organic pollutants, biological pollutants.
\end{abstract}

\section{Introduction}

Safe and reliable drinking water supplies are nowadays a concern of strategic significance worldwide. In many areas of the globe, the demand for high quality freshwater far exceeds available supply already. It is estimated, for example, [1] that over 2 million deaths each year are currently caused worldwide by pathogenic bacteria exposure linked to the consumption of unsanitary water. Beijing, China's capital, has reached a 3.6 billion $\mathrm{m}^{3}$ water consumption [2], far more than the 2.1 billion $\mathrm{m}^{3}$ locally available. 
The combined weight of: more stringent constraints placed on water companies to provide high quality drinking water, increasing water resources scarcity in many areas of the planet, reliance on marginal water bodies for supply, and the threat of hostile actions by political extremists and terrorist groups, that may willingly and deliberately cause contamination of otherwise safe supplies, are recent issues that have spurred demand for more efficient and robust online water monitoring technologies.

Availability of micro-biologically safe drinking water, is probably the most effective and economical way to ensure public health. In addition to "traditional" microbiological contamination by human waste, contamination of water sources by pesticides and herbicides is a growing problem worldwide. During the last two decades, studies revealed the growing presence of hazardous contaminants in wastewater effluents, including pesticides [3], natural and synthetic hormones [4], plasticizers, personal care products and pharmaceuticals compounds [5, 6].

A recent study estimated that there are 1415 human pathogens, about $12 \%$ are considered to be emerging ones. Their number continues to grow, on average at the rate of one new pathogen each year, as evidenced by relatively recent emergencies [7]. Such pathogens include organisms that can be transmitted directly through water or by water-related vectors; while a high proportion of water-borne disease is caused by classical pathogens such as Salmonella typhi and Vibrio cholerae, their spectrum is expanding.

As far as deliberate human hostile actions on urban water supplies, although none has been reported to date, in January 2002 the FBI circulated a reserved bulletin warning water industry managers that al-Qaida terrorists may have been studying American water-supply systems in preparation for new attacks [8].

Traditionally, quality parameters associated with drinking water provision were monitored using routine grab samples followed by laboratory analysis. This approach only allowed to capture small data sets, mostly unrepresentative of the true variance at the source, and allowed potentially important events to occur undetected. It is clear, that, in view of what just reported, this can no longer be considered a satisfactory procedure, and that online monitoring of water supplies, for a larger number of parameters than currently available, is quickly becoming an unavoidable choice [9].

\section{Definition and rationale for online monitoring}

Online monitoring is defined as the unattended sampling, analysis and reporting of a parameter; it produces a sequence of data at much greater frequency than is permitted by manual (grab) sampling, and it also allows real-time feedback for either process control, water quality characterization for operational or regulatory purposes, and/or for alert/alarm purposes.

Online monitoring can be carried out at onsite as well as in remote locations, and will deliver measurements at intervals of seconds-to-minutes. Clearly, online instrumentation must be placed at representative locations in the water system, and must be periodically maintained by qualified technical personnel. 
Monitoring requirements can be defined in relationship to:

- $\quad$ source water quality: (a) variability, in space and time (very low for groundwater, low for lakes, high for rivers); (b) vulnerability (type and location of possible contaminating activity), time-of-travel of a contaminant to the intake, effectiveness of barriers, control options after an alarm;

- water treatment: process optimization options and response times, sampling frequency must allow adequate process control;

- distribution systems: minimization of deterioration of water quality over time and distance, early detection of cross-connections and water losses; in addition, it must be considered that online monitors could have different sensitivity and selectivity according to the matrix and range of concentrations analyzed.

A multibarrier approach to drinking water quality protection, such as those that are mostly used by facilities worldwide, is based on the concept that contaminants must be subject to as many points of control/treatment (barriers) as possible, prior to tap. The ideal location for control of contaminants is as close to the (potential) source as possible. A source water with low vulnerability is therefore characterized by few potential contaminant activities, transit time longer than that required for laboratory analysis, and the presence of multiple physical barriers between contaminating activities and point of intake. In a source water with moderate vulnerability, online monitoring of surrogate parameters (such as TOC. DOC, $\mathrm{UV}_{254}, \mathrm{pH}$ and conductivity) may be considered to keep track of potential pollution. In a high vulnerability water source, online monitoring of chemical-physical-biological parameters (turbidity, $\mathrm{pH}$, conductivity, redox, fish toxicity) and surrogate parameters in addition to specific indicators (e.g. VOCs, phenols and specific toxicity tests) may be preferred. This is summarized in Table 1. This could list parameters for which online monitoring technology may not be widely available, nor field proved at the moment, but that may be useful for the given purpose.

The availability of real-time analytical information is one of the key benefits of online instrumentation: this information must however be conveyed to the appropriate user by means of a data collection and transmission system which is often referred to as SCADA, which consists of the individual online instruments, connected to Programmable Logic Controllers (PLCs) or Remote Telemetry Units (RTUs), that convert instrument outputs to the desired units, compare them to criteria set by the user, and generate signals for alarm or control to other process equipment. A host computer that can be used to visualize or store data, or to further utilize them for specific purposes, almost always complements these systems. 
Table 1: Online monitoring in multibarrier drinking water system (AWWA [9]).

\begin{tabular}{|l|l|l|}
\hline Activity & Monitoring strategy & Objectives \\
\hline $\begin{array}{l}\text { Contaminant source } \\
\text { identification }\end{array}$ & $\begin{array}{l}\text { Surrogate parameters (TOC, } \\
\text { DOC, UV 254, pH, conductivity); } \\
\text { specific parameters (related to } \\
\text { known sources of } \\
\text { contamination); biotest and } \\
\text { toxicity tests }\end{array}$ & $\begin{array}{l}\text { Define potential } \\
\text { contamination in relation to } \\
\text { vulnerability of source } \\
\text { water }\end{array}$ \\
\hline $\begin{array}{l}\text { Monitoring of } \\
\text { discharges into the } \\
\text { source water }\end{array}$ & $\begin{array}{l}\text { Specific organic/inorganic } \\
\text { contaminants }\end{array}$ & $\begin{array}{l}\text { Identify water pollution } \\
\text { accidents }\end{array}$ \\
\hline $\begin{array}{l}\text { BMPs/protection of } \\
\text { water source }\end{array}$ & $\begin{array}{l}\text { Hydrological parameters; } \\
\text { environmental parameters (solar } \\
\text { radiation, O, Chl) }\end{array}$ & $\begin{array}{l}\text { Prevent source } \\
\text { deterioration; } \\
\text { environmental management }\end{array}$ \\
\hline $\begin{array}{l}\text { Drinking water quality } \\
\text { protection }\end{array}$ & $\begin{array}{l}\text { Specific organic/inorganic } \\
\text { contaminants; treatment-related } \\
\text { parameters (Q, turbidity, pH, } \\
\text { TOC, DOC, etc.); } \\
\text { biotests/toxicity }\end{array}$ & $\begin{array}{l}\text { Allow appropriate } \\
\text { responses to contaminant } \\
\text { presence (intake shut-up, } \\
\text { additional treatment, } \\
\text { treatment adjustment) }\end{array}$ \\
\hline Emergency response & $\begin{array}{l}\text { Specific organic/inorganic } \\
\text { contaminants; biotests/toxicity }\end{array}$ & $\begin{array}{l}\text { Drinking water pollution } \\
\text { control; risk management; } \\
\text { treatment modification }\end{array}$ \\
\hline
\end{tabular}

\section{Online monitoring instrumentation overview}

Generally speaking, online monitoring instrumentation can be divided in:

- Physical monitors (Turbidity, particles, color, conductivity, TDS, hardness, alkalinity, acidity, streaming current, radioactivity, temperature, redox potential);

- Inorganic monitors ( $\mathrm{pH}$ and DO, disinfectants, such as chlorines and ozone, metals, fluoride, nutrients, cyanide);

- Organic monitors (carbon and hydrocarbons, UV adsorption, VOCs, pesticides, disinfection by-products);

- Biological monitors (nonspecific, algae, protozoa, pathogens);

- Hydraulic monitors (flow, level and pressure).

This paper will focus on the four former classes, discussing for each basic operating principles, and evaluation of the technology for online applications in the water distributing system.

\subsection{Physical monitors}

A wide array of technologies can be used for monitoring physical parameters, among them: light scattering/blocking (turbidity, particles, SS), light absorbance (color), electrochemical (conductivity, hardness, Redox), electrophoretic (streaming current), chemical tritration (alkalinity, acidity, hardness) and other (radioactivity, temperature) (Table 2). 
Table 2: $\quad$ Physical online monitors technology.

\begin{tabular}{|c|c|c|}
\hline Application & Most appropriate technology & Other technologies \\
\hline \multicolumn{3}{|l|}{ turbidity } \\
\hline $\begin{array}{l}\text { Low turbidity raw } \\
\text { water; clarified } \\
\text { water; filter effluent }\end{array}$ & $\begin{array}{l}\text { Single beam (tungsten or LED) } \\
\text { turbidimeter; modulated 4-beam } \\
\text { turbidimenter }\end{array}$ & \multirow{3}{*}{\begin{tabular}{|l} 
Particle counters; \\
particle monitors \\
EMERGING \\
TECHNOLOGIES \\
Laser light source $(660 \mathrm{~nm})$ \\
and improved optics \\
turbidimeters
\end{tabular}} \\
\hline $\begin{array}{l}\text { High turbidity raw } \\
\text { water }\end{array}$ & $\begin{array}{l}\text { Ratio turbidimeter; modulated } \\
\text { 4-beam turbidimeter }\end{array}$ & \\
\hline Filter backwash & $\begin{array}{l}\text { Transmittance turbidimeter; surface } \\
\text { scatter; ratio turbidimeter; } \\
\text { modulated 4-beam turbidimeter }\end{array}$ & \\
\hline \multicolumn{3}{|l|}{ Color } \\
\hline & $\begin{array}{l}\text { Online colorimeter; } \\
\text { spectrophotometer }\end{array}$ & \\
\hline \multicolumn{3}{|l|}{ TDS } \\
\hline & $\begin{array}{l}\text { 2-electrode conductivity probe; } \\
\text { electrodeless (toroidal) probes }\end{array}$ & \\
\hline \multicolumn{3}{|l|}{ Hardness } \\
\hline & $\begin{array}{l}\text { EDTA tritration online; } \\
\text { ion-specific electrodes (ISE) }\end{array}$ & \\
\hline \multicolumn{3}{|l|}{ Alkalinity } \\
\hline & Online alkalinity tritrator & \\
\hline
\end{tabular}

\subsection{Inorganic monitors}

Inorganic monitors technologies used in online mode to detect influent and effluent water quality, and for treatment process control are listed in Table 3.

Online monitoring of inorganic constituents is still in the early phase for many elements of interest to drinking water concerns. For metals, available technology is an adaptation to automatic operation mode of complex colorimetric methods developed for laboratory applications, and therefore turns out to be expensive and/or complex to operate, nor still suitable for installation in remote or unmanned sites. For many metals of interest in drinking water systems (As, $\mathrm{Cd}, \mathrm{Pb}, \mathrm{Hg}, \mathrm{Se}$, $\mathrm{Zn}$ ), online monitoring technologies do not exist at all. Some promise for future application comes from developments in optode technology, coupled with miniaturized spectrophotometry.

\subsection{Organic monitors}

The technology for online monitoring of organic compounds includes TOC analyzers, UV absorption and differential spectroscopy; it is much more developed than that for inorganics, for this reason, although neither EU nor US regulations require online monitoring of these substances, many drinking water utilities routinely use online organics monitoring to some degree. 
Table 3: Online inorganic monitor technology.

\begin{tabular}{|l|l|l|}
\hline Parameter & Currently applied technology & $\begin{array}{l}\text { Other technology } \\
\text { developments (not currently } \\
\text { /commonly available) }\end{array}$ \\
\hline $\begin{array}{l}\text { DO, pH } \\
\text { chlorine, nitrate, } \\
\text { fluoride }\end{array}$ & $\begin{array}{l}\text { Ion-selective electrodes (IESs); } \\
\text { membrane electrode sensors for DO } \\
\text { (polarographic or galvanic) }\end{array}$ & $\begin{array}{l}\text { Fiber-optics chemical sensors } \\
\text { (FOCSs or optodes) for pH, } \\
\text { DO; iodometric DO } \\
\text { measurement }\end{array}$ \\
\hline $\begin{array}{l}\text { Chlorine and } \\
\text { compounds }\end{array}$ & $\begin{array}{l}\text { Colorimetric (DPD); iodometric, } \\
\text { polarographic membranes and } \\
\text { amperometric methods; absorbance } \\
\text { (spectrometric) for ClO } 2\end{array}$ & $\begin{array}{l}\mathrm{ClO}_{2} \text { : iodometry, } \\
\text { amperometric meth. I, DPD, } \\
\text { amaranth, chlorophenol red, } \\
\text { LGB dye, ion chromatography }\end{array}$ \\
\hline Iron, manganese & $\begin{array}{l}\text { x-ray fluorescence (complex); } \\
\text { colorimetry }\end{array}$ & $\begin{array}{l}\text { Colorimetric, FOCS (ammonia) } \\
\text { ion sensitive gas membrane } \\
\text { electrodes }\end{array}$ \\
\hline $\begin{array}{l}\text { Ammonia, nitrite, } \\
\text { nitrate }\end{array}$ & Colorimetric, FOCS (cyanide) & \\
\hline $\begin{array}{l}\text { Phosphorous, } \\
\text { cyanide }\end{array}$ & \multicolumn{2}{|l}{} \\
\hline
\end{tabular}

Most organic compounds found in water absorb UV radiation: with a UV spectrometer it is therefore possible to estimate their concentration. Initially, a UV light source with the single wavelength of $254 \mathrm{~nm}$ was used for such measures, however, in recent years, instrumentation reading the entire UV-VIS spectrum (200-750 nm) has been developed and marketed [10]. UV absorption is a well-defined and commonly used methodology; evidence shows strong correlation between these measurements and organic carbon concentration measured with standard methods such as TOC or others (Figure 1). In addition, it has been shown that other parameters can be measured indirectly by correlating their concentration values to UV absorption in the full spectrum (Figure 2); several commonly sought organic compounds have typical absorption spectra that make their identification quite easy with appropriate instrumentation (Figure 3).
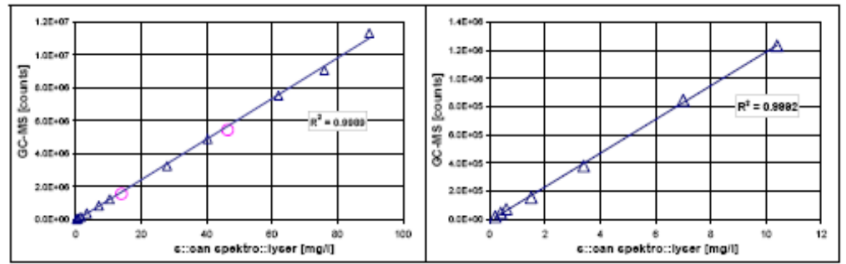

Figure 1: Calibration for benzene of online UV-VIS spectrometer against GC-MC laboratory methods, in distilled water (L) and groundwater (R) (S-can [10]). 


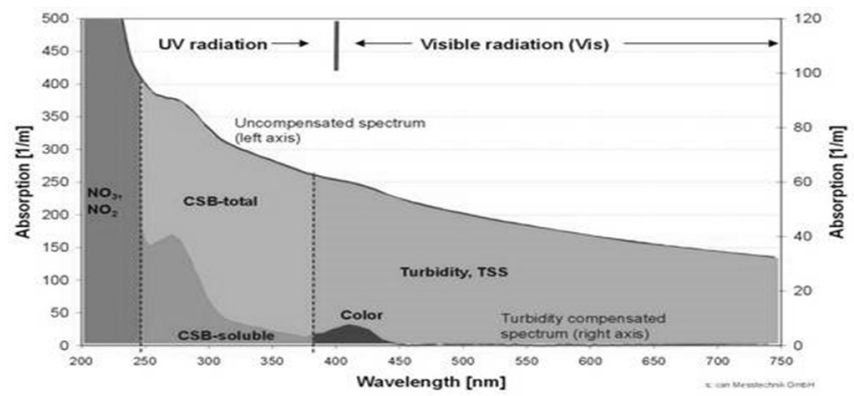

Figure 2: Correspondence between spectral absorption areas and quality parameters (courtesy S-can [10]).

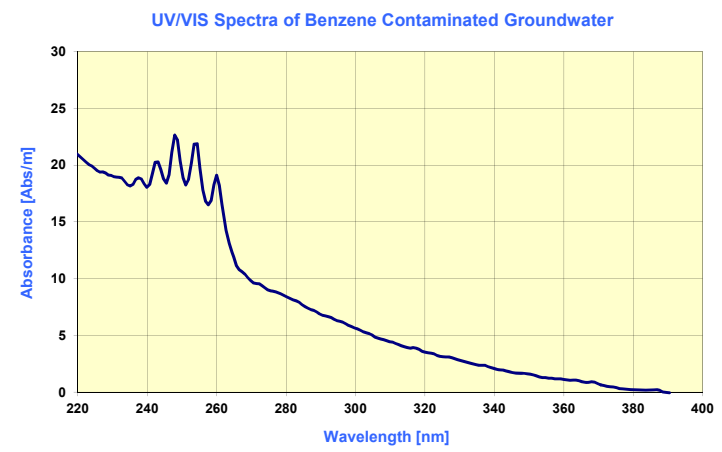

Figure 3: Typical spectral absorption image of benzene in water (S-can [10]).

Hydrocarbons in general are probably the main class of water pollutants found in surface and ground water (i.e., source water for drinking water systems). Methods for online hydrocarbon detection include: fluorometry, reflectivity, light scattering and turbidity measurement, ultrasonic methods, electrical conductivity, spectroscopy, gas-phase detection (after volatilization), resistance-based sensors; some of these methods, however, give just an indication of the presence/absence of oil on the water surface.

Volatile Organic Compounds (VOCs), including, among the others, aromatic compounds, halogenates and trihalometanes, are compounds that evaporate when exposed to air and can be of health concern when found in drinking water systems (trihalometanes are disinfection by-products - DBPs - that can be precursors to the formation of carcinogens). Their presence in drinking water can be a symptom of accidental pollution in the source water, of treatment failure/deficiency, or of incorrect disinfection procedures.

Current online monitoring technologies for VOCs include purge-and-trap gaschromatography with flame ionization (FID), electron capture (ECD) or photoionization detectors or mass spectrometry (MS). Detection limits for different substances vary according to the detector method.

Pesticides, including insecticides, fungicides and herbicides comprise triazines and phenlylurea compounds; they are monitored in drinking water systems in 
order to: detect accidental pollution in source waters, and check the effectiveness of treatment specifically designed to remove such substances. Online monitoring of pesticides can be carried out using composite techniques, such as:

- high pressure liquid chromatography (HPLC)/diode array (DA) detection, consists of extraction and enrichment, chromatographic separation and DA detection;

- gas chromatography (GC), consists of extraction and enrichment, GC separation and mass spectrometer (MS) detection;

- liquid chromatography/mass spectrometry, consists in extraction and enrichment, LC separation and MS, thermospray, electrospray or particle beam detection.

Each technique is capable to optimally detect a group of compounds, for example, HPLC /DA can be used to analyse; atrazine, chlortoluron, cyanazine, desethylkatrazine, diuron, hexazinone, isoproruton, linuron, metazachlor, methabenzthiszuron, metobrorumon, metolachlor, metoxuron, monolinuron, sebutylazine, simazine and terbutylazine.

In theory, any analytical laboratory method can be adapted for use as online measurement, provided that the requirements for consumables and manual intervention can be minimized: current online systems are often a "robotized" adaptation of known offline laboratory procedures, however, not always this solution is the most efficient one. A series of novel technologies, such as optochemical sensors, biosensors, and microbiological sensors are being tested for organics and hydrocarbon analysis. Advances already in use include differential UV spectroscopy for DBP detection and microphase solid-phase extraction (SPE) for the analysis of semivolatile organics [11].

\subsection{Biological monitors}

There are two basic types of biological monitors currently in use: those that use biological species as indicators of presence of contaminants (e.g. toxic chemicals), and those that screen for presence of biological species of concern (e.g. nuisance algae, pathogens). In common US terminology, the term biomonitor usually indicates the former, and is in fact used as synonymous with toxicity monitor. In EU terminology, biomonitor refers generally to all types of biologically-based systems.

At the present time, many existing biological monitors are quite new and can be considered experimental/unique applications. Table 4 shows an overview of the most common types of online biological monitors. Sensitivity of test organism to individual compounds must be determined initially.

Online biological monitors are a very active area of $R \& D$ due to increasing regulatory and public demand pressures. While bacterial-based systems show great sensitivity and ease of operation, and development in this area will likely derive from improved fingerprinting of organisms and maintenance cost reduction, most advances can be expected from protozoan monitor technology, with techniques in UV absorption/scattering analysis that may soon allow automated detection of Cryptosporidium and Giardia. Also, molecular techniques initially 
applied to the recognition of the genomic sequence of specific organisms in clinical applications [12] have also shown great potential for use in the detection of pathogens in water, and are producing extremely interesting results that could lead to widespread online use in the very next future.

Table 4: Online biological monitors.

\begin{tabular}{|c|c|c|}
\hline Technology & Measurement & Comments \\
\hline Fish tests & $\begin{array}{l}\text { Swimming pattern } \\
\text { Ventilation rate } \\
\text { Biolelectric field } \\
\text { Avoidance patterns }\end{array}$ & $\begin{array}{l}\text { Low sensitivity } \\
\text { Sophisticated requirements } \\
\text { Requires exotic "electric fish" species } \\
\text { Interpretation complex }\end{array}$ \\
\hline Daphnid tests & $\begin{array}{l}\text { Swimming activity } \\
\text { Behaviour }\end{array}$ & $\begin{array}{l}\text { Good performance, no determination } \\
\text { of causes }\end{array}$ \\
\hline Mussel tests & Shell positions/opening & \\
\hline Algae tests & $\begin{array}{l}\text { Fluorescence } \\
\text { (photosynthesis) }\end{array}$ & Commercial monitors available \\
\hline Bacteria tests & $\begin{array}{l}\text { Luminescence } \\
\text { Respiration of nitrifiers }\end{array}$ & $\begin{array}{l}\text { Commercially available, toxicity data } \\
\text { for over } 1000 \text { compounds }\end{array}$ \\
\hline Chlorophyll-a & Fluorometry & $\begin{array}{l}\text { Interference w/pigments, diss. } \\
\text { organics, sensitive to environmental } \\
\text { variables }\end{array}$ \\
\hline $\begin{array}{l}\text { Chlorophyll-a and } \\
\text { algal absorption }\end{array}$ & Reflectance radiometry & Commercial systems available \\
\hline Protozoan monitors & $\begin{array}{l}\text { Concentration; } \\
\text { centrifugation } \\
\text { Laser scanning } \\
\text { cytometry } \\
\text { Particle characterization } \\
\text { UV spectroscopy } \\
\text { Multiangle light } \\
\text { scattering; nucleic acid } \\
\text { molecules and } \\
\text { magnetized microbeads }\end{array}$ & $\begin{array}{l}\text { By filtration on membrane cartridge } \\
\text { with modified blood cell separators, } \\
\text { minimal operation time; analysis } \\
\text { possible within } 3 \text { minutes, particles } \\
\text { must be confirmed by trained } \\
\text { operator; measure particle } \\
\text { size/distribution, high number of false } \\
\text { positive and negative results; online } \\
\text { system, unlabeled parasites, } \\
\text { differentiation problems; successfully } \\
\text { tested in lab; oocysts detected within } \\
20 \text { minutes, not fully automated }\end{array}$ \\
\hline
\end{tabular}

\subsection{Indirect monitoring: "fingerprinting"}

Chemical fingerprinting describes the use of a unique chemical signature, isotopic ratio, mineral species, or pattern analysis to identify different chemicals. Optical fingerprinting by UV, VIS, and NIR absorption spectroscopy can be effectively achieved by low-cost and compact spectrometric devices, which can also be linked to an online diagnostic system, to directly identify some compounds (e.g. benzene) present in the water or to give an indication of the possibility of the presence of related compounds. 


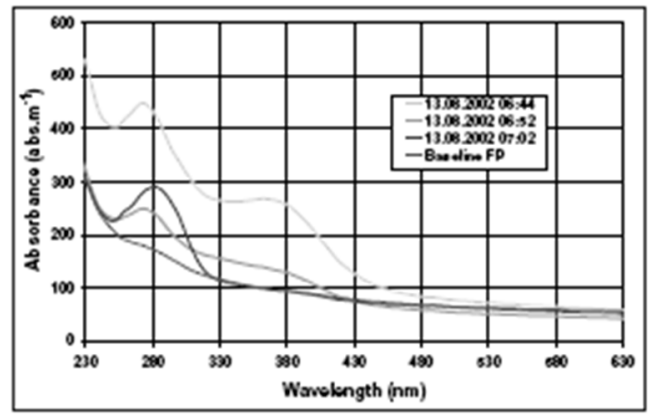

Figure 4: Optical fingerprinting of water indicating rapid quality changes.

In optical fingerprinting, a wide portion of the UV, VIS and NIR spectrum can be monitored simultaneously at high measurement frequency (minutes or fractions thereof); Figure 4 shows the spectral fingerprint of a typical municipal wastewater, in the range $230-630 \mathrm{~nm}$, together with three other spectral readings from the same source that were recorded within 18 minutes from the first. These show clearly different features, indicating a pronounced change in water quality. Although this alone will not, in general, indicate the compound or compounds responsible for the change (they will need to be further investigated, if a definite answer is desired), but that can nevertheless trigger an alert to the system's operator, indicating deviation from routine conditions.

\section{Upcoming technological developments}

\subsection{Early detection of contaminants}

The existence of Escherichia coli (E. coli) in drinking water is an important indicator of faecal pathogens and potential micro biological contamination. Currently available detection methods in drinking water distribution networks are inadequate, for multiple reasons: first of all, current methods are time consuming meaning that contamination will already have reached end-users before results are available; secondly, current sampling and analysis procedures lead to detection success rates of only 5 to $25 \%$ maximum. Research by scientists from Dutch KIWA shows that by using a network of on-line sensors, success rate can be increased to $80 \%$ [13]. The core of the LabOnline system is based on a combination of a concentrator unit and a sensor system using disposable chips, protecting the sensor system from cross-contaminations and guaranteeing reliable measurements. Initially designed for E.coli, the system is capable of detecting a broad group of microbiological contaminants like bacteria and viruses. KIWA also developed a sensor technology for pesticides based on an integrated optic chip, a biochemical transduction layer, (micro)-fluidics, electronics and data acquisition/system control software, called Optiqua MobileLab. The Optiqua MobileLab sensor for detection of pesticides will have low cost per analysis, 
detection of five pesticides (Simazine, Atrazine, Glyphosat, AMPA, BAM 2,6-dichlorbenzamide), detection of additional pesticides (at later stages), on site detection, prompt analysis results (minutes), high resolution (e.g. detection limits $0,05 \mu \mathrm{g} /$ ).

\subsection{Micro analysis system for water pathogen monitoring}

Knowledge of microbial genomes led to the development of molecular methods for detection of microbial pathogens in clinical specimens as well as. A wide array of molecular techniques has been applied to the study of microbiological water quality. Application of molecular techniques, such as PCR (Polymerase Chain Reaction) has generated valuable information on the occurrence, diversity, and biology of pathogens in water [14]. In addition, molecular methods demonstrate rapid detection and enhanced specificity compared to other analytical methods. A micro analysis system for water pathogen monitoring consists of a micro polymerase chain reaction (PCR) chip integrated with a continuous-flow microarray able to reduce analysis time from $24 \mathrm{hrs}$ to several hrs as compared with the existing EPA approved methods was presented by Yong et al. [16]. Pathogens are detected by the micro analysis system through DNA amplification, followed by direct transfer to a microarray for detection. In addition to single-species monitoring, the system shows potential in simultaneous monitoring of a range of pathogens.

\subsection{Two-dimensional GC screening for new contaminants}

Comprehensive two-dimensional gas chromatography ( $\mathrm{GCxGC})$, is a technique in which all the eluted compounds from a first column are submitted to a new separation in a second column with different selectivity. Contrary to gas chromatography (GC) which employs only one chromatographic column, GCxGC uses two columns, coupled in series, with a modulator at their junction. Due to its principle, GCxGC offers a much better capacity of separation and better sensitivity than conventional GC (3-5 fold higher than GC); therefore some compounds can be detected at the ng/L level. This technique can be applied [15] to the screening of wastewater and effluents samples. A large range of drugs (antidepressors, antibiotics, anticoagulants...), personal care products (sunscreens, antiseptics, cosmetics...) and carcinogens can thus be found in water and waste water samples. In addition to the above mentioned micropollutants, a wide variety of nitrogen aliphatic and aromatic structures that could act as DBP (disinfection by-products) precursors, can also be uncovered.

\subsection{Molecular online detection of waterborne pathogens}

A molecular technique, based on polymerase chain reactions to detect pathogens was proposed [17] to improve PCR diagnostics for routine analysis purposes, focusing on the processing of the sample, which is crucial for the robustness and the overall performance of the method. Objectives in sample preparation are to increase the concentration of the target organisms to the practical operating range 
of a given PCR assay; and to produce a purified DNA extract that would be representative of the initial water sample and would be free of PCR-inhibitory substances. This can be achieved by means of a two-step UltraFiltration (UF) procedure by using prototype hollow fiber UF cartridge, and a commercial UF centrifugal concentrator.

\section{Discussion and conclusions}

This paper overviewed existing instrumentation applicable to water supply online monitoring, and examined a few state-of-the-art technologies. It is clear that technological development in this field is very rapid, and that astonishing advances are anticipated in several areas (fingerprinting, optochemical sensors, biosensors, molecular techniques). Software applications, together with new generation sensors, are also contributing to the identification of otherwise difficultly monitored parameters.

In spite of the high technology being developed, monitoring costs are bound to become a lesser and lesser part of a water utility budget due to the fact that automation and technological simplification will abate the human cost factor (maintenance and other labour forms) and reduce significantly the complexity of procedures (with those, of reagent requirements, etc.).

Proper interpretation and use of the growing mass of water quality data that will become available through new technologies will allow better management of water resources, and water treatment and distribution facilities.

\section{References}

[1] WHO. Emerging issues in water and infectious disease. World Health Organization, Geneva, 2003.

[2] Beijing Water Authority. Data on water distribution and use in Beijing, China. Press Release, 2013.

[3] Öllers, S., Singer, H.P., Fässler, P. and Müller, S.R. Simultaneous quantification of neutral and acidic pharmaceuticals and pesticides at the low-ng/l level in surface waters. J. Chromatogr. A 911, (2), 225, 2001.

[4] Kolpin, D.W., Furlong, E.T., Meyer, M.T., Thurman, E.M., Zaugg, S.D., Barber, L.B. and Buxton H. Pharmaceuticals, hormones, and other organic wastewater contaminants in U.S. streams, 1999-2000: A national reconnaissance. Environ Sci Technol 36, 1202, 2002.

[5] Daughton, C.G. and Ternes, T.A. Pharmaceuticals and personal care products in the environment: agents of subtle change? Environ. Health Perspect 107, (6) 907, 1999.

[6] Jones, O.A.H., Voulvoulis, N. and Lester, J.N. Human pharmaceuticals in the aquatic environment, Environ. Technol. 22, (12), 1383, 2002.

[7] Cunliffe D.A. Emerging Enteric and Potentially Waterborne Pathogens in the Region. Proceedings, Singapore International Water Week Conference, June, Singapore, 2008. 
[8] IonLife website (ionlife.org). "How safe is our water? The threat of terrorism" Jan. 31, 2002.

[9] Awwa. Online Monitoring for Drinking Water Utilities. Cooperative Research Report. (E. Hargesheimer, O. Conio and J. Popovicova, Eds.) AWWA Research Foundation, Denver, CO., 2002.

[10] S-can company website http://www.s-can.at. S-can Gmbh, Vienna, Austria, 2014.

[11] Yongtao Li, E.J. George, E.M. Hansen, J.J. Toma, M. Werner and P.D. Smith. SPE Twin-PAL. Online in situ monitoring of semivolatile organic compounds in water. Proc. AWWA Water Quality Tech. Conf., Salt Lake City, UT., 2000.

[12] Bej, A.K. Molecular based methods for the detection of microbial pathogens in the environment. J Microbiol Methods, 53, 139-40, 2003.

[13] Koerkamp M.K., M. van Wijlen. Next generation sensors for detection of pesticides and E.coli in water. Proceedings, Singapore International Water Week Conference, June, Singapore, 2008.

[14] Loge, F.J., Thompson, D.E., \& Call, D.R. PCR detection of specific pathogens in water: a risk-based analysis. Environ Sci Technol, 36, 2754-9, 2002.

[15] Semard G., Z. Do-Quang, A. Bruchet. Screening of emerging contaminants in wastewaters using advanced GCxGC-TOFMS. Proceedings, Singapore International Water Week Conference, June, Singapore, 2008.

[16] Yong C.K., I.K. Lao, R. Murthy, H.M. Ji, C.Y. Teo, Christope Lay, H.H. Feng, W.T. Liu. Micro analysis system for water pathogen monitoring. Proceedings, Singapore International Water Week Conference, June, Singapore, 2008.

[17] Courtois S., K. Sebti and Z. Do-Quang. Universal concentration for large volumes of water samples before molecular detection of waterborne pathogens. Proceedings, Singapore Intl. Water Week Conference, June, Singapore, 2008. 